\title{
Palaeoenvironmental use of silicophytoliths in soils and palaeosols associated with Holocene volcanic ash deposits in north-western Argentina
}

Margarita Osterrieth ${ }^{1,2,3}$, María Fernanda Alvarez ${ }^{1,2,3}$, Juan Fernando Gallardo ${ }^{4}$, Julio Saavedra ${ }^{4}$, Jose-Luis Fernandez-Turiel ${ }^{5}$, Alejandro Rodriguez-Gonzalez ${ }^{6}$, and Francisco J. Perez-Torrado ${ }^{6}$, Marta Rejas ${ }^{5}$

${ }^{1}$ Instituto de Geología de Costas y del Cuaternario, FCEyN, UNMdP, Argentina.

${ }^{2}$ Instituto de Investigaciones Marinas y Costeras, CONICET-UNMdP, Argentina.

${ }^{3}$ Consejo Nacional de Investigaciones Científicas y Tecnológicas, CONICET, Argentina.

${ }^{4}$ IRNASA, CSIC, Spain.

${ }^{5}$ Institute of Earth Sciences Jaume Almera, ICTJA, CSIC, Spain.

${ }^{6}$ Instituto de Estudios Ambientales y Recursos Naturales (i-UNAT), Universidad de Las Palmas de Gran Canaria (ULPGC), Spain.

Corresponding author:

Jose-Luis Fernandez-Turiel, Institute of Earth Sciences Jaume Almera, ICTJA, CSIC, Solé I

Sabaris, 08028, Barcelona, Spain.

E-mail: jlfernandez@ictja.csic.es

\section{Abstract}

We compare the silicophytolith record of current soils and Holocene palaeosols from two sedimentary sequences in a region between the Chaco-Pampean Plain and the Puna (Tolombón section in Santa María Valley, and Tafí del Valle section in Tafí Valley), NW Argentina. These two geographic areas are separated by the Aconquija-Cumbres Calchaquíes ranges, a climatic barrier to the wet Atlantic winds. These sequences contain volcanic ash deposits recording two large eruptions occurred during Holocene in the Southern Puna in the Central Volcanic Zone of the Andes, from the Cueros de Purulla volcano (ca. 7820 BP) and the Cerro Blanco Volcanic Complex (ca. 4200 cal BP). These ash-fall deposits buried soils and preserved their silicophytolith record, allowing the use of this palaeoenvironmental proxy to clarify the vegetation prior these two volcanic events. The silicophytolith assemblages yield evidence for a mega/mesothermal xerophytic grassland when Tolombón palaeosol was 
formed, similar to the present-day environment in the Santa María Valley, with presence of $C_{4}$ grasses (Chloridoideae and Panicoidae). Instead, the climate was cooler and wetter ca. 4200 cal BP than currently in the Tafí Valley, increasing over time aridity and abundance of $\mathrm{C}_{4}$ grasses (Chloridoidae, Panicoideae), and decreasing the quantity of $C_{3}$ grasses (Pooideae). Prehistorical and historical land use also contributed to this change. The impact of these large volcanic ash-falls on vegetation did not translate in an abrupt change on phytodiversity. Results point out a stable arid environment during Holocene in the Santa María Valley whereas the Tafí Valley was more sensitive to environmental changes due to its location in the eastern slopes of Aconquija-Cumbres Calchaquíes ranges, more exposed to the wet Atlantic winds.

\section{Keywords}

silicophytolith, grassland, vegetation, volcanic ash, environment, Holocene, Argentina

\section{Introduction}

The palaeoenvironmental conditions of north-western Argentina between 8000 and 3500 a BP were subject of debate during a long period of time (Morales et al., 2018; Tchilinguirian and Morales, 2013). Some data of Central Andes supported a dry period (Grosjean et al., 2003), and other pointed out wet conditions (Latorre et al., 2003). The increasing progress of the research showed a more complex scenario, with important space-time variability of the palaeoenvironmental conditions (Tchilinguirian and Morales, 2013). This variability is largely due to the climate of Central Andes which is characterized by a complex interplay of largescale atmospheric circulation with local orographic effects (Garreaud et al., 2003; Garreaud, 2009; Neukom et al., 2015), being the easterly influx from the Amazon Basin the main moisture source for the region. As result, horizontal and altitudinal phytogeographical displacements are expected based on climate variations, especially in the eastern transitional areas. In addition, the palaeoenvironmental reconstruction in this setting may be hindered by the impact of short term catastrophic events such as the large volcanic eruptions (Ratto et al., 2013) and of long term features as tectonic activity (Trauth et al., 2003). However, the fast burial of soils by an ash fall may also play a key role in the preservation of their characteristics, including vegetation and, particularly, phytolith record (Dale et al., 2005).

Phytoliths (i.e., biogenic siliceous particles of plants) from palaeosols are increasingly gaining importance for deciphering past vegetation and environmental issues concerning archaeology, 
palaeoethnobotany and palaeoecology, particularly at sites where preservation of larger plantderived remains is poor (Katz, 2018; Osterrieth et al., 2009; Osterrieth et al., 2014; Rashid et al., 2019; Sharma et al., 2018). They reflect the vegetation growing around a giving site and may have a high degree of preservation in comparison with other vegetation remains, especially in palaeosols buried by volcanic ashes. For example, they were used to reconstruct the past vegetation and environment on volcanic regions of Japan (Kondo, 1977; Sase and Hosono, 2001; Shoji and Masui, 1971), New Zealand (Sase et al., 1988), and Mexico (JassoCastañeda et al., 2006; Vallejo Gomez, 2002).

In the present study, we extracted silicophytoliths from palaeosols buried by deposits of volcanic ashes of Cueros de Purulla volcano (ca. 7820 BP) and Cerro Blanco Volcanic Complex (ca. 4200 cal BP) eruptions in the Sierras Pampeanas, NW Argentina. The two sedimentary sequences studied are in a region between the Chaco-Pampean Plain and the Puna (Tolombón section in Santa María Valley, and Tafí del Valle section in Tafí Valley). Geographically, the study areas are separated by the Aconquija-Cumbres Calchaquíes ranges, a climatic barrier to the wet Atlantic winds. Silicophytoliths were used as potential indicators or proxies of the ancient vegetation and climate of these two areas before these large eruptions. The observed ancient silicophytolith assemblages are also compared with the current ones to identify potential environmental changes over time.

\section{Regional setting}

The study area is located in the northern end of the Sierras Pampeanas, NW Argentina (Fig. 1). These ranges consist of Precambrian-Lower Cambrian low-medium grade metamorphic rocks and Ordovician granites, covered by Tertiary sedimentary formations on the eastern side of the Santa María Valley (Ballato et al., 2019; Bossi et al., 2001; González et al., 2000; Rapela, 1976; Saavedra Alonso et al., 1984). Quaternary deposits include slope colluviums, alluvial veneers, alluvial fans, and volcanic ash deposits.

This region was affected at least by two large ash-falls during the Holocene and their remains may be observed in many localities (Fernandez-Turiel et al., 2015; Fernandez-Turiel et al., 2013; Fernandez-Turiel et al., 2019; Sampietro-Vattuone and Peña-Monné, 2016). These two ash deposits were correlated mineralogically, chemically and geochronologically to the volcanic sources, both distant around $200 \mathrm{~km}$ from the respective volcanic vents in the 
Southern Puna (Fernandez-Turiel et al., 2015; Fernandez-Turiel et al., 2013; Fernandez-Turiel et al., 2019) (Fig. 1). The oldest ash deposits were correlated with the Cerro Paranilla Ash of the Calchaquíes Valleys, whose age was established close to $7820 \pm 830$ a BP (Hermanns et al., 2000), and were associated with the Cueros de Purulla volcano (Fernandez-Turiel et al., 2016; Fernandez-Turiel et al., 2019). The thickness of these deposits ranges from tens of decimetres to several meters. The ash-fall deposits are made up of rhyolitic pyroclasts, with angular to sub-angular blocky shapes containing tubular vesicles. The dominant phenocrysts are biotite, which is the distinguishing feature of these deposits in the field, feldspars (plagioclase > Kfeldspar), quartz, titanomagnetite, and ilmenite. Amphiboles and clinopyroxenes are minor contents. Apatite, allanite-epidote, muscovite, titanite and zircon can be found in trace amounts. Lithic fragments are very rare (Fernandez-Turiel et al., 2019).

The most recent ash deposits (ca. 4200 cal BP) were related to the Cerro Blanco Volcanic Complex (Fernandez-Turiel et al., 2015; Fernandez-Turiel et al., 2013; Fernandez-Turiel et al., 2019). The stratigraphic sequence of these deposits starts with around $10 \mathrm{~cm}$ series of parallel, very thin beds of ash. The upper part of the deposit shows poorly defined stratification and its thickness varies from tens of decimetres to several meters. The ash-fall deposits are mainly composed of cuspate and blocky glass shards ( $\sim 9 \%)$, but also contains feldspars ( $\sim 5 \%)$, quartz $(\sim 3 \%)$, and biotite $(<2 \%)$, often as free crystals. Minor contents include magnetite, ilmenite, clinopyroxene, orthopyroxene, amphiboles, allanite-epidote, muscovite, titanite, and zircon. Lithic fragments are very rare. This eruption could be the biggest during the past five millennia in the Central Volcanic Zone of the Andes, and it is possibly one of the largest Holocene eruptions in the world (Fernandez-Turiel et al., 2013; Fernandez-Turiel et al., 2019).

Two well exposed outcrops were selected for this study due to it has not been possible to locate single stratigraphic series with the two ash deposits. The section with the Cueros de Purulla ash deposit is close to the village of Tolombón, where the ash layer occurs in a hanging terrace. The section with the Cerro Blanco ash deposit is near the cemetery of Tafí del Valle. To facilitate the explanation, the sections are named Tolombón and Tafí del Valle, respectively. The Tolombón section is in the northern end of the intermountain graben of Santa María Valley in the Valles Calchaquíes, Province of Salta (long. $65^{\circ} 58^{\prime} 03.15^{\prime W}$, lat. $26^{\circ} 08^{\prime} 14.57^{\prime \prime S}$, altitude $1640 \mathrm{~m}$ a.s.I.) (Figs. 1 and 2). The Tafí del Valle section is in the homonymous basin in the Aconquija ranges, Province of Tucumán (long. $65^{\circ} 42^{\prime} 36.23^{\prime \prime} \mathrm{W}$, lat. $26^{\circ} 53^{\prime} 01.70^{\prime \prime S}$, altitude 1925 m a.s.I.) (Figs. 1 and 3). 
Rainfall is concentrated during summer, meanwhile winters are dry. The Aconquija-Cumbres Calchaquíes ranges obstruct the humid winds coming from Atlantic. Climatically, Tolombón is characterized by strong aridity, with cold desert climate (classified as BWk by the KöppenGeiger system). The average annual temperature is $16.2^{\circ} \mathrm{C}$ and the average annual rainfall is $211 \mathrm{~mm} \mathrm{yr}^{-1}$ (Merkel, 2018). Instead, Tafí del Valle's cold semi-arid climate is classified as BSk according Köppen and Geiger system. The average annual temperature is $14.6^{\circ} \mathrm{C}$, and the average annual rainfall is $410 \mathrm{~mm} \mathrm{yr}^{-1}$ (Merkel, 2018).

The current soils predominantly belong to the taxonomic orders of Aridisol in Tolombón and Entisol in Tafí del Valle (Puchulu and Fernandez, 2014). Both soils are subject to water and aeolian erosion. Furthermore, the slope processes act vigorously upon the current soils, and cattle rising is a permanent activity.

Phytogeographycally, Tolombón sampling site is located within the Monte province, and Tafí del Valle in the Chacoan province (district of high-elevation grasslands), both within the Chacoan dominion (Karlin et al., 2017; Oyarzabal et al., 2018). Most plants in the study area produce calciphytoliths, and to a lesser extent silicophytoliths.

The Tolombón landscape is mainly covered by sparse xerophytic vegetation, mainly steppe grass and shrubs (Larrea divaricata or "jarilla" -common name of this plant in Spanish-, Cercidium australis or "brea", Lipia turbinate or "poleo", Senna aphilla or "pilchana", Plectocarpa ronguesii or "rodajilla", and Spartium junceum or "retama") (Carrizo and Grau, 2014). Trees are scarce: Prosopis nigra or "algarrobo negro", P. alba or "algarrobo blanco", Schinus molle or "molle", Acacia caven or "churqui", A. aroma or "tusca", A. visco or "arca", and Geoffroea decorticans or "chañar". There are also specimens of "cardón" (Trichocereus pasacana, T. terscheckii and T. poco).

The landscape of Tafí del Valle consists of grasslands with few native trees, such as $P$. alba, $A$. caven, A. aroma and Salix humboldtiana or "sauce criollo" (Brown, 2013). Among the herbaceae or prairie vegetation, the Poaceae predominate (Cynodon dactylon, Poa annua, Sporobolus indicus, Bromus unioloides, Paspalum humboldtianum, Eriochloa peruviana, and several species of Stipa). There are also species of the families Astereaceae (Acanthostyles buniifolius, Perezia multiflora, Gnaphalium sp. and Senecio sp.), Verbenaceae (Verbena sp.), and Onagraceae (Oenothera sp.). 


\section{Material and methods}

Fieldwork was carried out according to pedostratigraphic norms of soil and palaeosol surveys. Description of soils and palaeosols follows Soil taxonomy (Soil Survey Staff, 1999), colour was determined according to the Munsell Soil Colour Chart. In each section, after detailed preliminary field studies, modal soil profiles were defined.

Sampling was carried out on the current soils and the palaeosols buried by volcanic ashes, located in the Tolombón and Tafí del Valle sections. The Tolombón section was sampled in four soil profiles (Fig. 2) and the Tafí del Valle section was in two profiles (Fig. 3). Two palaeosols were observed in one profile of each section. As result, five samples of palaeosol and four of current soil were obtained in the Tolombón section, and three samples of palaeosol and two of current soil were obtained in the Tafí del Valle section.

Each sample ( $1000 \mathrm{~g}$ ) consisted of 12 replicates of the surface horizon of the current soils and of the palaeosol horizons. These integrated samples were sifted through 125 and $62 \mu \mathrm{m}$ mesh; $5 \mathrm{~g}$ were extracted from a quartered sample to determine the percentage of silicophytoliths against the total sum of mineralogical components by centrifugation $(3 \mathrm{~min}$ ) of the whole sample followed by heavy liquid separation with sodium polytungstate (Alvarez et al., 2008). The quantitative content and morphological analysis of silicophytoliths was performed under petrographic microscope (Olympus BX51), and characteristics that are more detailed were analysed with a Jeol JSM-6460LV scanning electron microscope (SEM) equipped with an energy dispersive X-ray spectrometer (EDS). The description and classification was carried out following the ICPN code (International Code for Phytolith Nomenclature 1.0) (Madella et al., 2005), through a count of 500 to 700 particles per sample. Soil organic carbon (SOC) was determined by the Walkley and Black technique (Allison, 1965).

\section{Results}

\subsection{Tolombón section}

The Tolombón section is summarized in Fig. 2c. The palaeosol or soil buried by the volcanic ash deposit shows morphological characteristics indicating a high pedogenesis, such as colour 
(7.5YR 5/2 brown (h, humid), and 7.5YR 6/4 light brown (d, dry), psephitic texture with a low content of pelites and finer sands, and the presence of bioturbation. The palaeosol shows two palaeohorizons in TB4 sampling site (2CA and 2CA', upper and lower, respectively). The soil organic content (SOC) is higher than in current soils, ranging between 7 and $12 \mathrm{mg} \mathrm{C} \mathrm{g}^{-1}$ (Table 1). Volcanic shards are abundant in the current soils (Fig. 4a, b, h) and scarce in the palaeosols.

The silicophytolith content in palaeosols was barely $4-6 \%$ of the total mineral fraction of study (Table 1). The predominant morphotypes were elongates of various sizes with crenated to smooth edges (Figs. 4e, g; Fig. 5, median 23\%, n=4, palaeosol 2CA). The rondels are abundant and sometimes are partially altered (Fig. 5 ; median $12 \%, n=4$, palaeosol 2CA). Lower numbers of saddle morphotypes, indicators of communities of $\mathrm{C}_{4}$ metabolic routes, were also found (Fig. 4d; Fig. 5; median 9\%, n=4, palaeosol 2CA). Bilobates, of various sizes and types are common (Fig. 4i), and they are weathered and fractured to a considerable extent (Fig. 5; median $8 \%, n=4$, palaeosol 2CA). The bulliforms, typical of gramineae, are from medium to large size (Fig. 5, median 13\%, n=4, palaeosol 2CA). Short-cells (Fig. 4k) and few point-shaped ones with well-defined points were also observed. There were very few articulated silicophytoliths, mostly smooth elongates, of the epidermis of gramineae (Fig 4c). Dicotyledons were the only non-grass silicophytolith determined (Fig. 4I, m). In general, $20 \%$ of the content of silicophytoliths was undefined, which hinders their interpretation.

The current soils have a high psephite content, with more than $80 \%$ of the volume occupied by metamorphic and igneous rocks fragments, with very low o null content of silt and clay, low pedogenetic development and some limitations for the retention of humidity. Colour is 7.5YR $3 / 2$ dark brown (h), and 7.5YR 5/4 light brown (d). The ash deposit colour is 7.5YR 8/ white (h and s). The SOC content is between 2 and $7 \mathrm{mg} \mathrm{C} \mathrm{g}^{-1}$ (Table 1). They show traces of permanent large-scale cattle-breeding.

The content of silicophytoliths in current soils was about 3-4 \% of total studied mineral fraction of sample (Table 1). In general, they all show a good preservation (Fig. 4a, b). The composition of the silicophytolith assemblage is practically the same than the observed in palaeosol, predominating elongates and to a lesser extent bulliforms (Fig. 4 j), saddles, rondels, bilobates, short cells, crosses (Fig. 4f), and point-shaped. The only non-grass phytoliths identified were dicotyledons. One sample also presented a high concentration of remains of diatoms. These morphologies indicate gramineae in general, and they correspond to the scarcity of vegetation 
observed, such as xerophytic bushes and gramineae, predominantly pooids and panicoids and, to a lesser extent, chloridoids.

The characteristics of buried soil by volcanic ash and current soil are practically identical. SOC values, silicophytolith total content and assemblage reflect an arid climate with similar patterns of vegetation at least ca. $7820 \mathrm{BP}$ and today. The aridity together with a fast burial by the ash-fall played probably a decisive role in the preservation of the silicophytoliths. The silicophytolith assemblages are characterized by the dominance of unicellular phytoliths, mainly pooids, chloridoids and panicoids, indicating the abundance of communities of $C_{3}$ and $\mathrm{C}_{4}$ metabolic routes of gramineae within the scarcity of xerophytic vegetation. The articulated silicophytoliths in the palaeosol are associated to rapid burial processes (Osterrieth et al., 2009). The low number of diatoms in current soil is attributed to ephemeral small puddles and/or cattle-breeding.

\subsection{Tafí del Valle section}

The stratigraphy of Tafí del Valle section is presented in Fig. 3b. The morphological characteristics of palaeosol or soil buried by the volcanic ash in this section show a higher pedological development in comparison to the current soils. The wide cover of ash level, averaging a thickness of $2 \mathrm{~m}$ (Fig. 3), has preserved the pedological characteristics of these soils, which allow inferring a little transformation of its organic and inorganic components of buried soils. The soil texture is from silty-sand to fine-sandy, being the structure massive to weak and with small granules. Colour is 7.5YR $2 / 2$ dark brown (h) and 7.5YR 4/2 brown (d). The palaeosol shows two palaeohorizons in TF1 sampling site (2AC and $2 \mathrm{AC}^{\prime}$, upper and lower, respectively). The palaeosol has a high SOC content, ranging from 72 to $80 \mathrm{mg} \mathrm{C} \mathrm{g}^{-1}$ (Table 1). Volcanic shards are abundant in the current soils (Fig. 6a, b) and scarce in the palaeosols.

The silicophytolith content in the buried soil was $17-28 \%$ for palaeosols $2 \mathrm{AC}$ and $2 \mathrm{AC}^{\prime}$ (Table 1). The prevalent morphotypes were elongates of several sizes, with edges ranging from crenate to smooth (Figs. 6o; Fig. 7, 20-26\%). Rondels (Figs. 6g, h; Fig. 7, 10-22\%) and bilobates (Figs. 6i-l; Fig. 7, 9-15\%) show smooth edges, both convex and concave, and are indicators of $C_{3}$ and $C_{4}$ Panicoideae and Poaceae $\left(C_{3}\right)$ grasses. Saddle morphotypes, indicators of communities of $\mathrm{C}_{4}$ metabolic routes, were also found (Figs, 6e, f; Fig. 7, 6-10\%). Bulliforms (Fig. $6 n, r$, s; Fig. 7, 3-7\%) of large to medium size are also common, typical of grass. Cylindrical 
sulcate tracheids, typical cells of conductive tissue, are scarce (Fig. 6t). Dicotyledons were also rare (Fig. 6u; Fig. 7).

The current soils are developed on a massive ash deposit. They consist of more than $95 \%$ of the volume occupied by sand-silty ash size, have a low pedogenetic development and some limitations for the retention of humidity. They show traces of permanent large-scale cattlebreeding. Colour of soil is 7.5YR 4/2 brown (humid, h), and 7.5 5/2 light brown (dry, d). Colour of ash deposit is 7.5YR 8/ white ( $\mathrm{h}$ and s). The topsoil organic carbon content is 7-8 $\mathrm{mg} \mathrm{C} \mathrm{g}^{-1}$ (Table 1).

The silicophytoliths of current soils reach $6 \%$ of the total mineralogy of the sample (Table 1), a value substantially lower to that found in palaeosols, where achieve up to $28 \%$. In general, all display a moderate to good level of preservation. The silicophytoliths undefined, mainly due to their bad state of preservation, reached $25 \%$. The most abundant morphotypes were elongates (Fig. 6q), saddles and rondels; less frequent are the bilobates, bulliforms, short cells and pointshaped (Fig. 6m). Dicotyledoneae phytoliths are scarce (Fig. 6u). Considerable amounts of diatoms were found in the surface horizon (Fig. 6d). Volcanic ash shards are common (Figs. 6a, b), in addition to feldspars, biotite (Fig. 6c), opaque and accessory minerals, and lithic fragments, among others. The observed morphotypes indicate gramineae in general, with a predominance up to $19 \%$ of Chloridoideae, typical $C_{4}$ gramineae, and in a lesser extent Poaceae from $C_{3}$ and $C_{4}$ communities associated with the presence of bilobates of the stipa and panicoid types (Fig. 5).

When we compare the soil buried by ash deposits of the ca. 4200 cal BP eruption of Cerro Blanco Volcanic Complex with the current soil, we observe clear differences. There has been a tenfold decrease of SOC, and approximately a fourfold reduction of silicophytolith total content. Furthermore, the biodiversity expressed by silicophytolith assemblages indicates an increase of aridity. This setting may be related to a higher level of vegetation cover ca. $4200 \mathrm{cal}$ $\mathrm{BP}$, in turn related to a higher pedological development of soil at the moment of ash-fall burial in comparison to the current soil. Diagnostic grass silicophytoliths, i.e., rondel, bilobate and saddle, were more abundant than non-diagnostic grass silicophytoliths, i.e., elongate and bulliforms, in palaeosol and current soil. These silicophytolith assemblages indicate the predominance of gramineae. The remains of diatoms in current soils are related to ephemeral small puddles and/or cattle-breeding practices. 


\section{Discussion}

In this study new silicophytolith data of the Holocene in Santa María and Tafí valleys, northern Sierras Pampeanas in NW Argentina, were provided by the analysis of two stratigraphic sections with soils buried by ash deposits of two large volcanic eruptions, ca. $7820 \mathrm{BP}$ and ca. $4200 \mathrm{cal} B P$.

Before to discuss these data, it is important to point out that the silicophytolith content with respect to the total mineralogy of the horizons and sediments is an aspect that must be considered relevant, since it is a conspicuous expression of the relation between vegetal cover, soil, and environment (Osterrieth et al., 2009). Unfortunately, this data is not readily available, and is rarely present in most of the studies on silicophytoliths. The usual procedure, instead, consists in submitting quantitative data in samples that concentrate amorphous silica fractions. This prevents evaluating the impact of the quantitative relation as a clear expression of the previous vegetal cover of the soils (Osterrieth et al., 2014). There has been a steady increase in silicophytolith studies in pedosedimentary and archaeological sequences in the last twenty years. Therefore, it is important to move forward, taking on the taphonomic aspects of its presence, absence or diagenesis, among others, according to the scheme established by Osterrieth and contributors (Osterrieth et al., 2009; Osterrieth et al., 2014).

Moreover, when interpreting the results, the orography is a very relevant feature. The Aconquija-Cumbres Calchaquíes ranges reach more than $5000 \mathrm{~m}$ altitude and are a major barrier for Atlantic humidity. This huge orographic obstacle introduces significant local differences in vegetation patterns due to the interaction between large-scale atmospheric circulation and orography (Garreaud et al., 2003; Garreaud, 2009; Neukom et al., 2015). As result, climate and orography define $\mathrm{N}-\mathrm{S}$ ecoregions that were already well established at least since the late Pleistocene (Anzótegui et al., 2017).

Mega/mesothermal grass silicophytoliths were the most abundant in the two sections, following most of them the $\mathrm{C}_{4}$ photosynthetic pathway (Chloridoideae, Panicoideae). Moreover, significant quantities of $C_{3}$ grasses (Pooideae) were also observed. The $C_{4}$ grasses tend to occupy a drier niche than their $C_{3}$ relatives, evidencing a climate characterized by higher aridity (Bonomo et al., 2013; Contreras and Zucol, 2018; Twiss, 1987). 
The Tolombón section is representative of the Santa María Valley, an intramontane arid valley located at the west of Aconquija-Cumbres Calchaquíes ranges. Instead, the Tafí del Valle section is illustrative of the semi-arid conditions on the eastern slopes of these mountains. The silicophytolith assemblages of Tolombón section of ca. 7820 BP palaeosol and the current soil are similar, which allows us to infer a poor vegetation cover in relation to a low pedogenetic development of these Entisols. This is coherent with the prevalent arid climate conditions in the Santa María Valley during Holocene, although showing some variations on humidity over time, as inferred from the data of archaeology and geomorphology (Agnolin and Carbonelli, 2017; Carbonelli, 2014; Collantes and González, 2012; Gómez Augier and Caria, 2012; Peña-Monné et al., 2015; Peña Monné and SampietroVattuone, 2018; Somonte and Baied, 2013).

The eastern location of Tafí Valley about the climatic barrier of Aconquija-Cumbres Calchaquíes ranges makes this area more susceptible to environmental changes than the Santa María Valley. As result, more horizontal and altitudinal phytogeographical displacements are expected in the Tafí Valley based on climate variations. The palynological record in a paleolagoon of Tafí Valley illustrates the vegetation and climate evolution during a long period of the Holocene (Garralla et al., 2001). This study confirmed the occurrence of a gramineous steppe (Poaceae, Amaranthaceae-Chenopodiaceae and Asteraceae) with scarce presence of elements of vegetation of humid environments before ca. 10,350 a BP. This environment changed by increase of the humidity to gramineous steppe vegetation with shrubby elements of fresh climate, and the development of the lagoon which was finally clogged by the ca. 4200 a BP ash-fall of Cerro Blanco Volcanic Complex. The silicophytolith assemblage that we found in the soil buried by this ash-fall in the Tafí del Valle section allow us to infer a cooler and wetter environment in comparison to the current, being consistent with the before-mentioned findings.

After the catastrophic event of the Cerro Blanco ash-fall, drier conditions prevailed in the Tafí Valley. The palaeoenvironmental reconstruction since 4.2 ka showed a geomorphological incision phase that affected all the river courses of the area (Sampietro-Vattuone and PeñaMonné, 2016), followed by an accumulation phase in wetter conditions ending ca. 1300 a AD, coinciding with the Little Ice Age (LIA). The subsequent incision phase was followed by an unstable environmental period until the present. During the last two thousand years, climate was not the only triggering factor on the landscape changes and humans had a growing influence (Sampietro Vattuone et al., 2018a; Sampietro Vattuone et al., 2018b). 
In taphonomic sense, it is important to consider the effects of recurrent cattle-breeding developed in the area under analysis: an extra source of silicophytoliths in manure. These sources are confirmed by the presence of broken silicophytoliths, and diatoms, which existence is related to a hydric level that the current soils no longer exhibit. Possible vertical and subhorizontal migrations are related to the predominantly psephytic and sandy texture of the soils and the topography and microtopography of the current relief, while the texture of the paleosols is essentially sandy and it evolved into a terraced palaeorelief, flatter than the current one. All this may have favoured the preservation of silicophytoliths.

Finally, there is also the need for additional studies of silicophytolith assemblages, to obtain a more precise taxonomic understanding that will allow decreasing the percentage of not identified elements and thus reducing the uncertainty on the determination of vegetation variability.

\section{Conclusions}

We describe the silicophytolith assemblages of two soils buried by huge ash-falls of two Holocene volcanic eruptions from the southern Puna plateau, in NW Argentina, and the corresponding assemblages in the current soils. The older buried soil (ca. 7820 BP) was formed in an arid environment and has a silicophytolith assemblage practically identical to the current soil in the Santa María Valley, reflecting xerophytic grassland by the presence of $C_{4}$ grasses (Chloridoidae and Panicoidae). Instead, the younger buried soil (ca. 4200 cal BP) was developed under more humid conditions than the prevailing on the current soil of Tafí Valley, allowing to infer over time an increase of aridity and abundance of $\mathrm{C}_{4}$ grasses (Chloridoidae and Panicoidae) and a decrease of the quantity of $C_{3}$ grasses (Pooideae).

Phytolith assemblages discriminated both areas due to the vegetation patterns vary according to their west and east location against the climate barrier of Aconquija-Cumbres Calchaquíes ranges, with wetter conditions on the eastern slopes of these ranges due to the contribution of the Atlantic wet winds. Moreover, they recorded the vegetation change between the eruptions times and the present-day. The Santa Maria Valley seems that was a very stable arid environment during Holocene; the Tafí Valley, by contrast, had a more changing climate. 
Relationships between vegetation and impact of studied volcanic ash-falls seem that it did not translate in an abrupt change on vegetation diversity.

These results point out the opportunities for using silicophytoliths to elucidate palaeoenvironmental changes in the geological record at regional scale and provide a baseline for further investigation of potential impacts of volcanism on vegetation.

\section{Acknowledgements}

We thank J. C. Carracedo, J. I. Carrizo and G. Esteban, for their assistance with fieldwork. We thank the anonymous reviewers for their comments and ideas that helped to improve an earlier version of the manuscript. Financial support was provided by Project QUECA (MINECO, CGL2011-23307), Agencia-Ministerio de Ciencia y Técnica (PICT-1583-2013) and Universidad Nacional de Mar del Plata (EXA 643/13). This study was carried out in the framework of the Research Consolidated Groups GEOVOL (Canary Islands Government, ULPGC) and GEOPAM (Generalitat de Catalunya, 2017 SGR 1494).

\section{References}

Agnolin, A., Carbonelli, J.P., 2017. Diseños de puntas de proyectil en el valle de Santa María (Catamarca, Argentina): una aproximación a la ocupación cazadora-recolectora. Chungará (Arica) 49, 511-528.

Allison, L.E., 1965. Organic Carbon, in: Black, C.A. (Ed.), Methods of Soil Analysis. Part 2. Chemical and Microbiological Properties. American Society of Agronomy, Madison, pp. 1367-1378.

Alvarez, M.F., Borrelli, N., Osterrieth, M., 2008. Extracción de biominerales silíceos en distintos sedimentos utilizando dos técnicas básicas, in: Korstanje, M.A., Babot, M.P. (Eds.), Matices interdisciplinarios en estudios fitolíticos y de otros microfósiles, Oxford, pp. 31-38.

Anzótegui, L.M., Mautino, L.R., Garralla, S.S., Herbst, R., Robledo, J.M., M.Y., H., 2017. Paleovegetación cenozoica del noroeste argentino, in: Muruaga, C.M., Grosse, P. (Eds.), Relatorio del XX Congreso Geológico Argentino. Ciencias de la Tierra y Recursos Naturales del NOA. Asociaición Geológica Argentina, San Miguel de Tucumán, pp. 767781.

Ballato, P., Brune, S., Strecker, M.R., 2019. Sedimentary loading-unloading cycles and faulting in intermontane basins: Insights from numerical modeling and field observations in the NW Argentine Andes. Earth and Planetary Science Letters 506, 388-396. 
Bonomo, M., Catriel Leon, D., Osterrieth, M., Steffan, P., Borrelli, N., 2013. Paleoenvironmental studies of Alfar archaeological site (mid-Holocene; Southeastern Pampas of Argentina): Silicophytoliths, gastropods and archaeofauna. Quaternary International 287, 34-46.

Bossi, G.E., Georgieff, S.M., Gavriloff, I.J.C., Ibañez, L.a.M., Muruaga, C.M., 2001. Cenozoic evolution of the intramontane Santa María basin, Pampean Ranges, northwestern Argentina. Journal of South American Earth Sciences 14, 725-734.

Brown, A.D., 2013. Plan de manejo, Reserva Provincial La Angostura. Äreas Protegidas de Tucumán, Fundación ProYungas, San Miguel de Tucumán, p. 69.

Carbonelli, J.P., 2014. Evidencias paleoambientales y de producción lítica en la cantera taller Ampajango, Valle de Yocavil (Catamarca, Argentina). La Zaranda de Ideas. Revista de Jóvenes Investigadores en Arqueología 11, 9-26.

Carrizo, J., Grau, A., 2014. Plantas silvestres de los Valles Calchaquíes, Guía visual. Universidad Nacional de Tucumán, Tucumán.

Collantes, M.M., González, L.M., 2012. Mecanismos del proceso de desertificación en el valle de Santa María, provincia de Tucumán (Argentina). Acta Geológica Lilloana 24, 108122.

Contreras, S.A., Zucol, A.F., 2018. Late Quaternary vegetation history based on phytolith records in the eastern Chaco (Argentina). Quaternary International in press.

Dale, V.H., Delgado-Acevedo, J., MacMahon, J., 2005. Effects of modern volcanic eruptions on vegetation, in: Ernst, G.G.J., Marti, J. (Eds.), Volcanoes and the Environment. Cambridge University Press, Cambridge, pp. 227-249.

Fernandez-Turiel, J.L., Ratto, N., Perez-Torrado, F.J., Rodriguez-Gonzalez, A., Rejas, M., Lobo, A., 2016. A large eruption convulsed in prehistoric times an extensive area of Catamarca, Southern Central Andes, NW Argentina, EGU General Assembly, Vienna, pp. EGU2016-10120.

Fernandez-Turiel, J.L., Saavedra, J., Perez-Torrado, F.J., Rodriguez-Gonzalez, A., Carracedo, J.C., Lobo, A., Rejas, M., Gallardo, J.F., Osterrieth, M., Carrizo, J.I., Esteban, G., Martínez, L.D., Gil, R.A., Ratto, N., Baez, W., 2015. The ash deposits of the 4200 BP Cerro Blanco eruption: the largest Holocene eruption of the Central Andes, EGU General Assembly, Vienna, pp. EGU2015-3392.

Fernandez-Turiel, J.L., Saavedra, J., Perez-Torrado, F.J., Rodriguez-Gonzalez, A., Carracedo, J.C., Osterrieth, M., Carrizo, J.I., Esteban, G., 2013. The largest Holocene eruption of the Central Andes found, AGU Fall Meeting, San Francisco, USA.

Fernandez-Turiel, J.L., Perez-Torrado, F.J., Rodriguez-Gonzalez, A., Saavedra, J., Carracedo, J.C., Rejas, M., Lobo, A., Osterrieth, M., Carrizo, J.I., Esteban, G., Gallardo, J., Ratto, N., 2019. The large eruption $4.2 \mathrm{ka}$ cal BP in Cerro Blanco, 1 Central Volcanic Zone, Andes: Insights to the Holocene eruptive deposits in the southern Puna and adjacent regions. Estudios Geologicos 75, e088.

Garralla, S.S., Muruaga, C., Herbst, R., 2001. Lago el Rincón. Holoceno del departamento de Tafí del Valle. Provincia de Tucumán (Argentina): Palinología y facies sedimentarias, XI Simposio Argentino de Paleobotánica y Palinología. Asociación Paleontológica Argentina, pp. 91-99.

Garreaud, R., Vuille, M., Clement, A.C., 2003. The climate of the Altiplano: observed current conditions and mechanisms of past changes. Palaeogeography, Palaeoclimatology, Palaeoecology 194, 5-22.

Garreaud, R.D., 2009. The Andes climate and weather. Adv. Geosci. 22, 3-11.

Global Volcanism Program, 2013. Volcanoes of the World, v. 4.7.4. Venzke, E (ed.).

Smithsonian Institution. Downloaded 01 Dec 2018

(https://volcano.si.edu/volcano.cfm?vn=355210). http://volcano.si.edu/ 
Gómez Augier, J.P., Caria, M.A., 2012. Los paleoambientes y los procesos culturales en el Noroeste Argentino: una aproximación desde la arqueología de Tucumán. Acta Geológica Lilloana 24, 80-97.

González, O.E., Viruel, M.E., Mon, R., Tchilinguirian, P., Barber, E.L.G., 2000. Hoja geológica 2766-II San Miguel de Tucumán, Boletín 245. Servicio Geológico Minero Argentino. Instituto de Geología y Recursos Minerales, Buenos Aires.

Grosjean, M., Cartajena, I., Geyh, M.A., Nuñez, L., 2003. From proxy data to paleoclimate interpretation: the mid-Holocene paradox of the Atacama Desert, northern Chile. Palaeogeography, Palaeoclimatology, Palaeoecology 194, 247-258.

Hermanns, R.L., Trauth, M.H., Niedermann, S., McWilliams, M., Strecker, M.R., 2000. Tephrochronologic constraints on temporal distribution of large landslides in northwest Argentina. Journal of Geology 108, 35-52.

Jasso-Castañeda, C., Sedov, S., Gama-Castro, J.E., Solleiro-Rebolledo, E., 2006. Paleosuelos: índices del paleoambiente y de la estabilidad del paisaje del Nevado de Toluca. Terra Latinoamericana 24, 151-161.

Karlin, U.O., Karlin, M.S., Zapata, R.M., Coirini, R.O., Contreras, A.M., M., C., 2017. La Provincia Fitogeográfica del Monte: límites territoriales y su representación. Multequina 26, 6375.

Katz, O., 2018. Plant Silicon and Phytolith Research and the Earth-Life Superdiscipline. Frontiers in plant science 9, 1281-1281.

Kondo, R., 1977. Opal phytoliths, inorganic, biogenic particles in plants and soils. Japan Agricultural Research Quarterly 11, 198-203.

Latorre, C., Betancourt, J.L., Rylander, K.A., Quade, J., Matthei, O., 2003. A vegetation history from the arid prepuna of northern Chile $\left(22-23^{\circ} \mathrm{S}\right)$ over the last 13500 years. Palaeogeography, Palaeoclimatology, Palaeoecology 194, 223-246.

Madella, M., Alexandre, A., Ball, T., 2005. International code for phytolith nomenclature 1.0. Annals of Botany 96, 253-260.

Merkel, A., 2018. Climate data for cities worldwide. AM Online Projects, Oedheim.

Morales, M.R., Bustos, S., Oxman, B.I., Pirola, M., Tchilinguirian, P., Orgeira, M.J., Yacobaccio, H.D., 2018. Exploring habitat diversity of mid-holocene hunter-gatherers in the SouthCentral Andes: Multi-proxy analysis of Cruces Core 1 (TC1), Dry Puna of Jujuy, Argentina. Journal of Archaeological Science: Reports 18, 708-721.

Neukom, R., Rohrer, M., Calanca, P., Salzmann, N., Huggel, C., Acuña, D., Christie, D., A., Morales, M.S., 2015. Facing unprecedented drying of the Central Andes? Precipitation variability over the period AD 1000-2100. Environmental Research Letters 10, 084017.

Osterrieth, M., Madella, M., Zurro, D., Fernanda Alvarez, M., 2009. Taphonomical aspects of silica phytoliths in the loess sediments of the Argentinean Pampas. Quaternary International 193, 70-79.

Osterrieth, M.L., Fernandez Honaine, M., Borrelli, N., Fernández Alvarez, M., 2014. Silicophytoliths in representative soils of the Southeast Pampean Plains, Argentina, in: Gomes Coe, H.H., Osterrieth, M. (Eds.), Synthesis of some phytolith studies in South America (Brazil and Argentina). Nova Science Publishers, pp. 215-242.

Oyarzabal, M., Clavijo, J., Oakley, L., Biganzoli, F., Tognetti, P., Barberis, I., Maturo, H.M., Aragón, R., Campanello, P.I., Prado, D., Oesterheld, M., León, R.J.C., 2018. Unidades de vegetación de la Argentina. Ecología Austral 28, 40-63.

Peña-Monné, J.L., Sancho-Marcén, C., Sampietro-Vattuone, M.M., Rivelli, F., Rhodes, E.J., Osácar-Soriano, M.C., Rubio-Fernández, V., García-Giménez, R., 2015. Geomorphological study of the Cafayate dune field (Northwest Argentina) during the last millennium. Palaeogeography, Palaeoclimatology, Palaeoecology 438, 352-363.

Peña Monné, J.L., SampietroVattuone, M.M., 2018. Paleoambientes holocenos del valle de Tafí (Noroeste Argentino) a partir de registros morfosedimentarios y geoarqueológicos. Boletín Geológico y Minero 129, 671-691. 
Puchulu, M.E., Fernandez, D.S., 2014. Características y Distribución Espacial de los Suelos de la Provincia de Tucumán, in: Moyano, M.S., Puchulu, M.E., Fernandez, D.S., Vides, M.E., Nieva, S., Aceñolaza, G. (Eds.), Geología de Tucumán. Colegio de Graduados en Ciencias Geológicas de Tucumán.

Rapela, C.W., 1976. El basamento metamórfico de la región de Cafayate, provincia de Salta. Aspectos petrológicos y geoquímicos. Revista de la Asociación Geológica Argentina 31, 203-222.

Rashid, I., Mir, S.H., Zurro, D., Dar, R.A., Reshi, Z.A., 2019. Phytoliths as proxies of the past. Earth-Science Reviews In press.

Ratto, N., Montero, C., Hongn, F., 2013. Environmental instability in western Tinogasta (Catamarca) during the Mid-Holocene and its relation to the regional cultural development. Quaternary International 307, 58-65.

Saavedra Alonso, J., Toselli, A.J., Rossi de Toselli, J.N., 1984. Aspectos geológicos y geoquímicos del granito peralumínico de Loma Pelada, Tafí del Valle, Tucumán. Revista de la Asociación Geológica Argentina 39, 12-27.

Sampietro-Vattuone, M.M., Peña-Monné, J.L., 2016. Geomorphological dynamic changes during the Holocene through ephemeral stream analyses from Northwest Argentina. CATENA 147, 663-677.

Sampietro Vattuone, M., Peña Monne, J.L., Roldán, J., Maldonado, M., Lefebvre, M., Vattuone, M., 2018a. Human-driven geomorphological processes and soil degradation in Northwest Argentina: A geoarchaeological view. Land Degradation \& Development 29, 3852-3865.

Sampietro Vattuone, M.M., Peña Monné, J.L., Maldonado, M.G., Sancho Marcén, C., Báez, W., Sola, A., Blasi, A., 2018b. Cambios ambientales durante el Holoceno superior registrados en secuencias morfosedimentarias fluvio-eólicas del Valle de Santa María (Noroeste Argentino). Boletín Geológico y Minero 129, 647-669.

Sase, T., Hosono, M., 2001. Phytolith record in soils interstratified with late Quaternary tephras overlying the eastern region of Towada volcano, Japan, in: Meunier, J.D., Colin, F. (Eds.), Phytoliths: Applications in Earth Science and Human History. CRC Press, pp. 5776.

Sase, T., Hosono, M., Utsugawa, T., Aoki, K., 1988. Opal phytolith analysis of present and buried volcanic ash soils at Te Ngae Road Tephra Section, Rotorua Basin, North Island, New Zealand, soil-vegetation relationship for last 20, 000 yrs. The Quaternary Research (Daiyonki-Kenkyu) 27, 153-163.

Sharma, R., Kumar, V., Kumar, R., 2018. Distribution of phytoliths in plants: a review. Geology, Ecology, and Landscapes, 1-26.

Shoji, S., Masui, J.-I., 1971. Opaline silica of recent volcanic ash soils in Japan. Journal of Soil Science 22, 101-108.

Soil Survey Staff, 1999. Soil taxonomy: A basic system of soil classification for making and interpreting soil surveys, 2nd ed. Natural Resources Conservation Service. U.S. Department of Agriculture.

Somonte, C., Baied, C.A., 2013. Edad mínima de exposición de superficies en canteras-taller: reflexiones en torno a las primeras dataciones mediante microlaminaciones del barniz de las rocas (VML) para el noroeste argentino. Chungará (Arica) 45, 427-445.

Tchilinguirian, P., Morales, M.R., 2013. Mid-Holocene paleoenvironments in Northwestern Argentina: Main patterns and discrepancies. Quaternary International 307, 14-23.

Trauth, M.H., Bookhagen, B., Marwan, N., Strecker, M.R., 2003. Multiple landslide clusters record Quaternary climate changes in the northwestern Argentine Andes. Palaeogeography, Palaeoclimatology, Palaeoecology 194, 109-121.

Twiss, P.C., 1987. Grass opal phytoliths as climatic indicators of the Great Plains Pleistocene, in: Johnson, W.C. (Ed.), Quaternary environments of Kansas. Kansas Geological Survey. Guidebook Series 5, pp. 179-188. 
Vallejo Gomez, E., 2002. Morfologia e intemperismo de fitolitos, en suelos modernos y paleosuelos de la parte central del eje neovolcanico. Universidad Nacional Autónoma de México, México, p. 105. 


\section{Figure captions}

Fig. 1. Study area: (a) Holocene volcanic centres in the Andean Central Volcanic Zone (data from Global Volcanism Program, 2013). NVZ, Northern Volcanic Zone; CVZ, Central Volcanic Zone; SVZ, Southern Volcanic Zone; and AVZ, Austral Volcanic Zone. (b) Studied stratigraphic sections and eruptive centres of ash-falls that buried the palaeosols focus of this work.

Fig, 2. Tolombón section: (a) sampling profiles (TB1 to TB4); (b) detail of soil buried by the ashfall of Cueros de Purulla volcano (ca. 7820 BP); (c), synthetic stratigraphic profile.

Fig, 3. Tafí del Valle section: (a) sampling profiles (TF1 and TF2); (b) synthetic stratigraphic profile.

Fig. 4. Tolombón section. General views with petrographic microscope (PM) (a) and scanning electron microscope (SEM) (b) (profile-horizon, TB1-CA). Silicophytolith morphotypes described in current soil and palaeosols: c. articulated (PM) (TB4-2CA). d. saddle (PM) (TB22CA). e. elongated (SEM) (TB1-2CA). f. cross (PM) (TB4-CA). g. elongate (PM) (TB3-2CA). $\boldsymbol{h}$. volcanic ash and bilobate (SEM) (TB3-CA). i. bilobate (PM) (TB4-2CA). j. bulliform cell (PM) (TB2-CA). k. short cell weathered (PM) (TB3-2CA). I-m. dicotyledons (PM) (TB1-2CA). V: volcanic ash. Bar: $10 \mu \mathrm{m}$.

Fig. 5. Relative abundances of silicophytolith morphotypes in Tolombón section in soil (s) and palaeosols (2CA and 2CA').

Fig. 6. Tafí del Valle section. a. General petrographic microscope (PM) view (profile TF1-CA). b and c. General scanning electron microscope (SEM) views (b, TF2-CA; c, TF1-2CA). d. diatom (PM) (TF1-CA). Silicophytolith morphotypes described in current soil and palaeosols: e. saddle (PM) (TF1-2CA). f. sadlle (SEM) (TF2-2CA). g. rondel (SEM) (TF1-2CA'). h. rondel (PM) (TF22CA). i. bilobate (PM) (TF1-2CA). j-k. bilobate (SEM) (TF2-2CA'). I. bilobate (PM) (TF2-2CA). $\mathbf{m}$. point-shaped (PM) (TF1-CA). n. bulliform (SEM) (TF2-2CA'). o. elongate (SEM) (TF1-2CA). p. articulated (PM) (TF2-2CA). q. elongated (PM) (TF2-CA). r. bulliform cell (PM) (TF2-2CA). s. bulliform cell weathered (PM) (TF1-2CA'). t. cylindrical sulcate tracheids, typical cells of conductive tissue (PM) (TF1-2CA). u. dicotyledon (PM) (TF2-2CA). V: volcanic ash. S: silicophytolith. B: biotite. Bar: $10 \mu \mathrm{m}$. 
Fig. 7. Relative abundances of silicophytolith morphotypes described in current soil (s) and palaeosols ( $2 \mathrm{AC}$ and $2 \mathrm{AC}^{\prime}$ ) of Tafí del Valle section. 


\section{Table 1}

Soil organic carbon (SOC) and silicophytolith content of soils (s) and palaeosols ( $p$ ) of Tolombón (TB) and Tafí del Valle (TF) sections.

\begin{tabular}{lrr}
\hline Sample & $\begin{array}{c}\text { SOC } \\
\mathrm{mg} \mathrm{Cg}^{-1}\end{array}$ & $\begin{array}{c}\text { Silicophytoliths } \\
\text { (\% over total } \\
\text { mineral } \\
\text { content) }\end{array}$ \\
\hline TB1-CA & 5 & 3 \\
TB1-2CA & 7 & 4 \\
TB2-CA & 5 & 3 \\
TB2-2CA & 7 & 4 \\
TB3-CA & 2 & 4 \\
TB3-2CA & 9 & 5 \\
TB4-CA & 7 & 4 \\
TB4-2CA & 12 & 4 \\
TB4-2CA' & 8 & 6 \\
TF1-CA & 7 & 6 \\
TF1-2AC & 72 & 28 \\
TF1-2AC' & 76 & 19 \\
TF2-CA & 8 & 6 \\
TF2-2AC & 80 & 17 \\
\hline
\end{tabular}




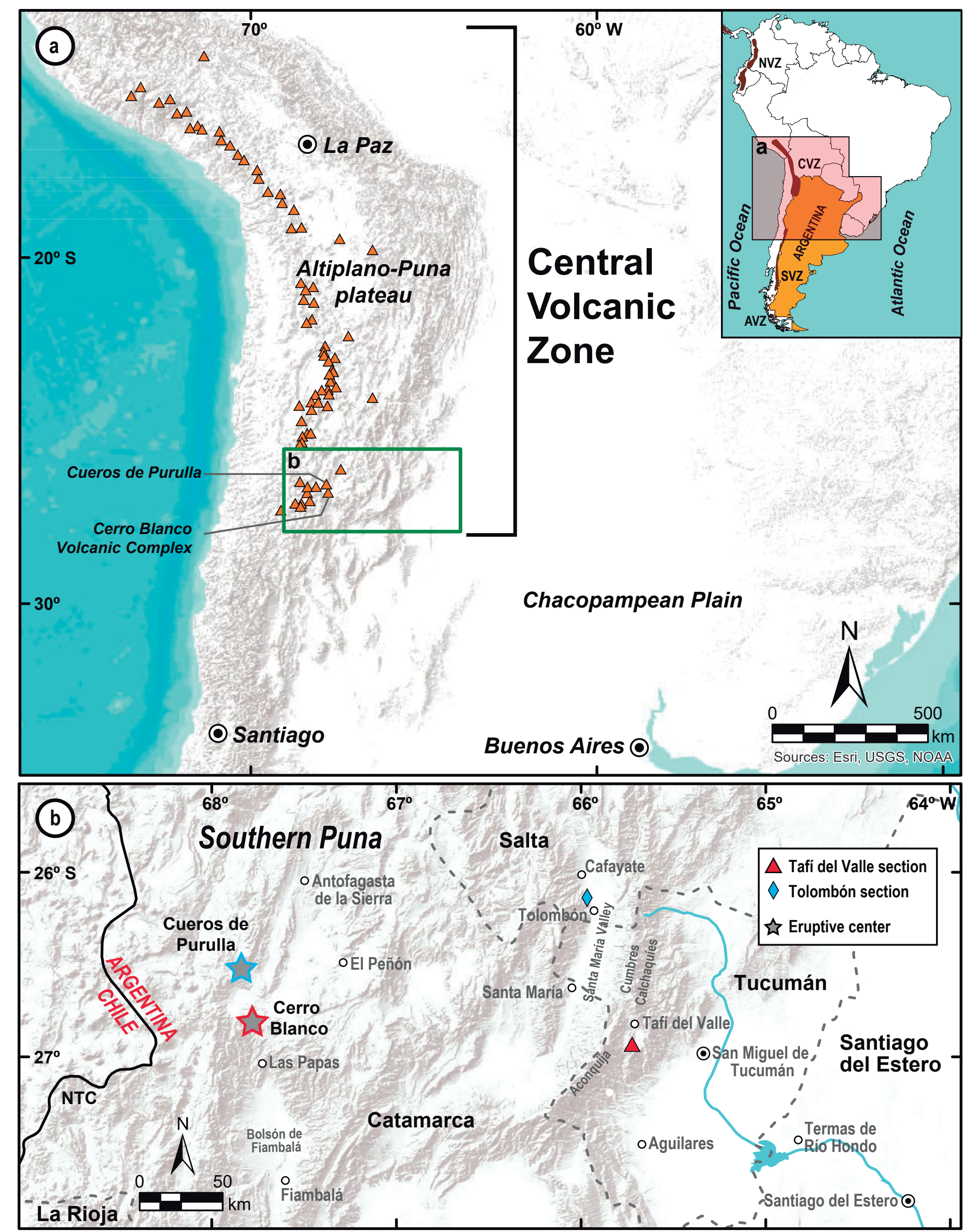




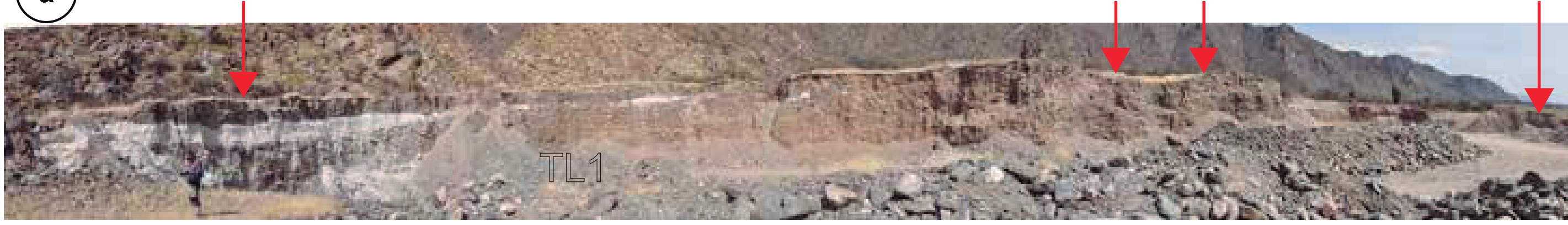

(b)

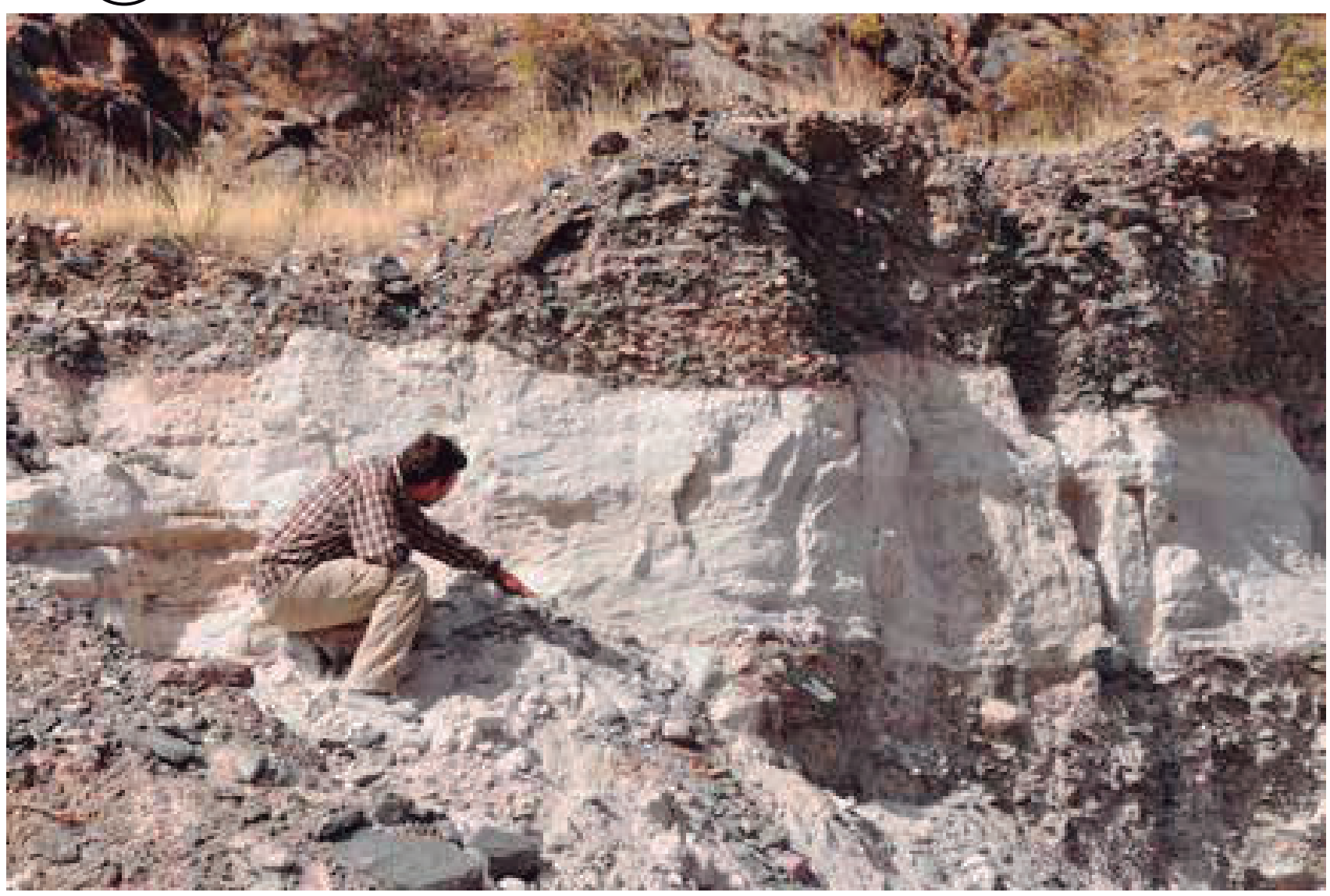

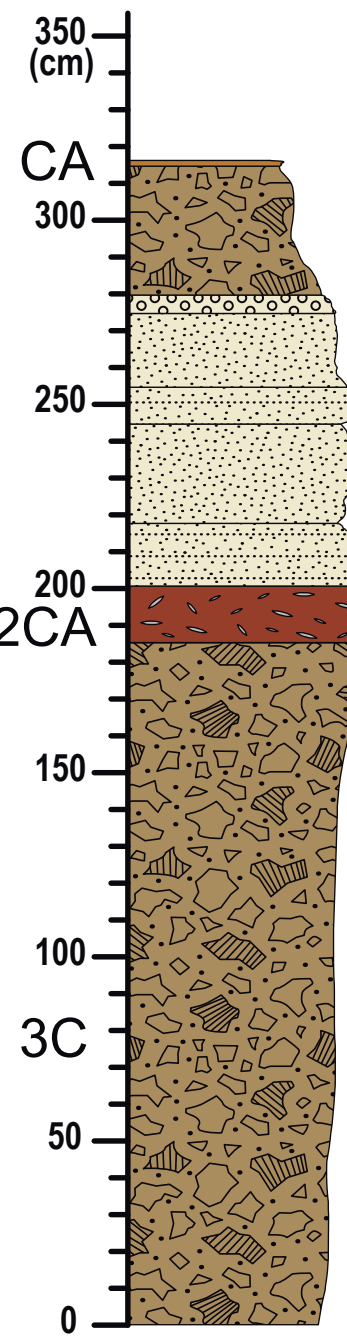

Debris flood deposits

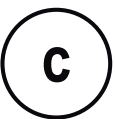

Figure 2 

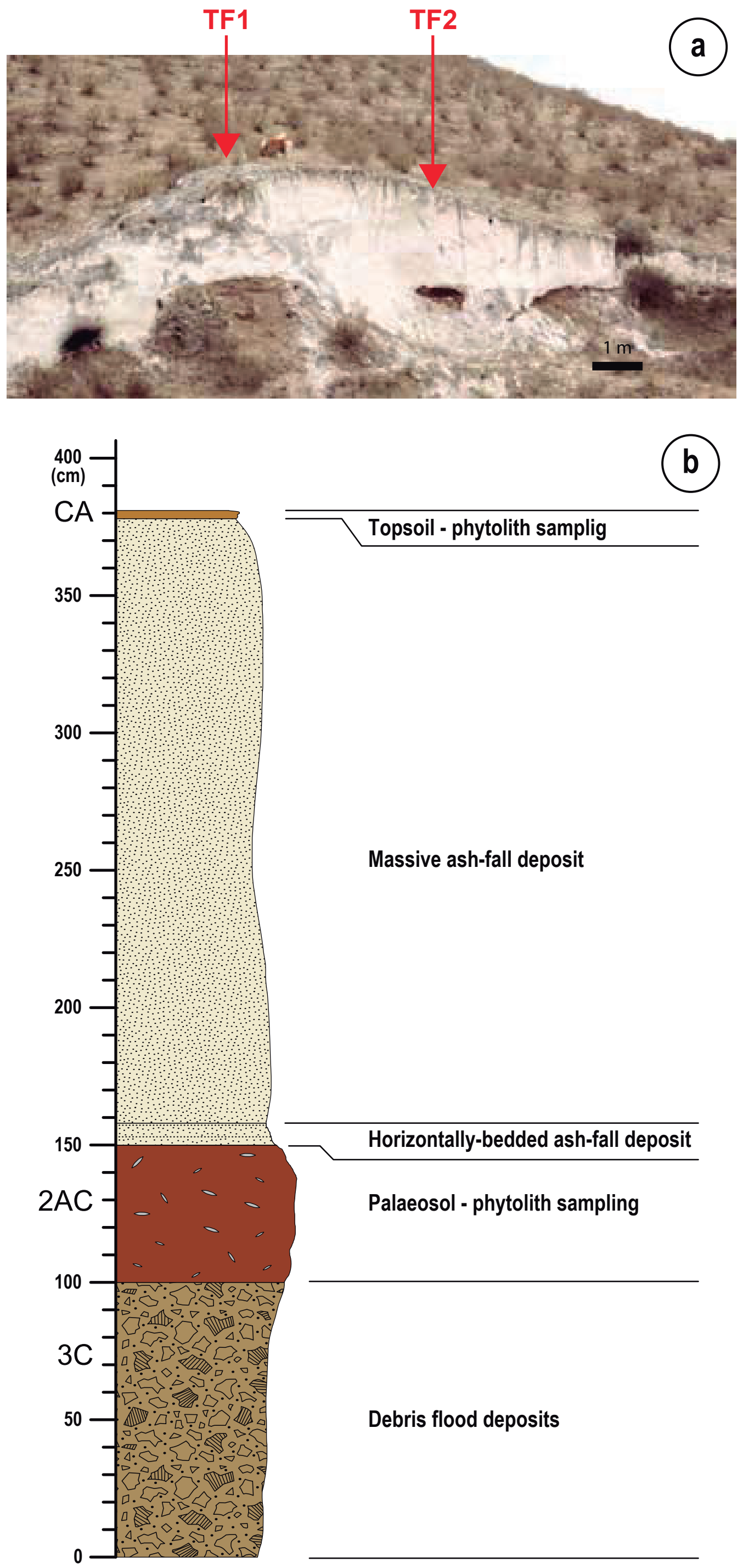

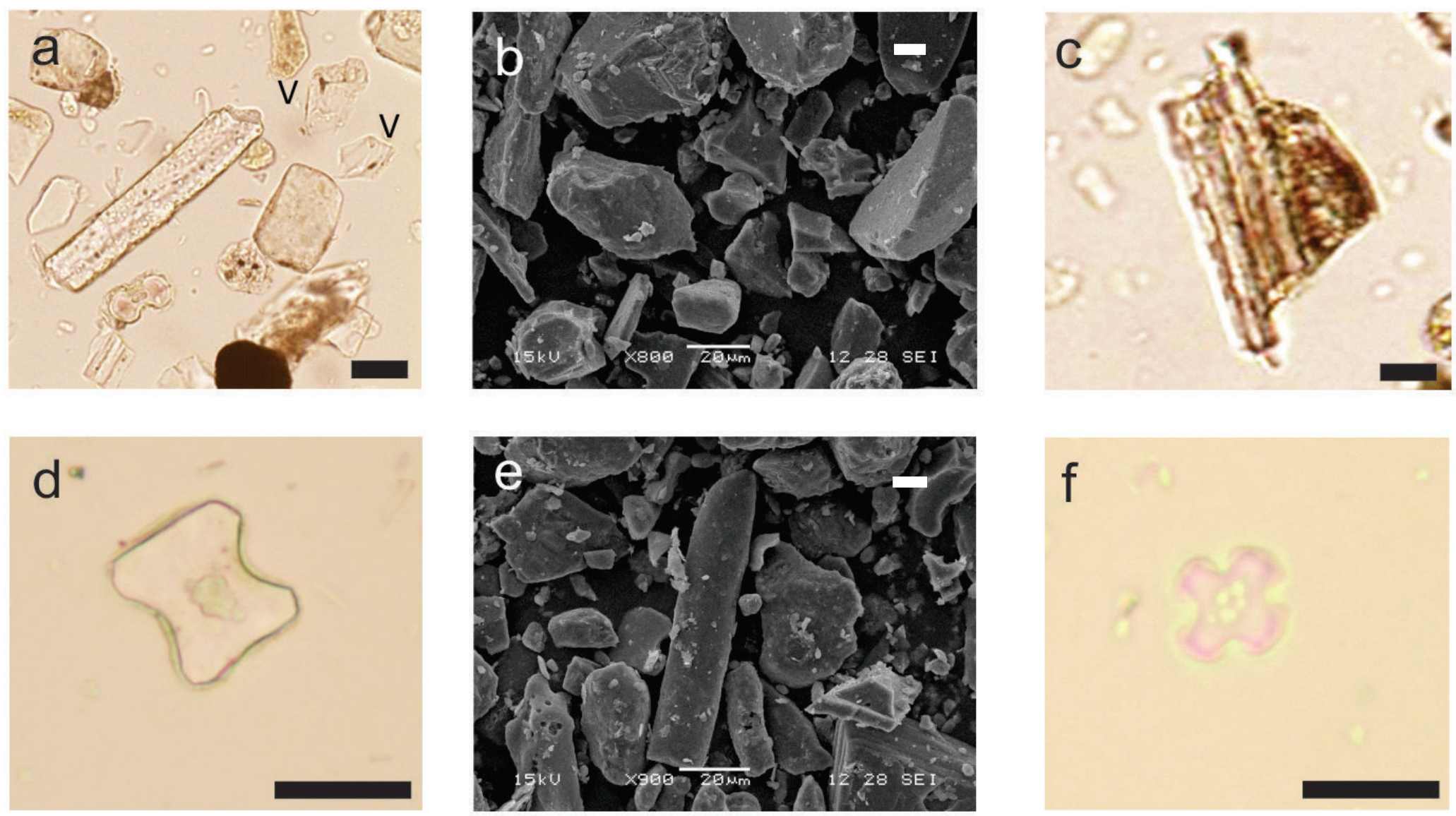

f
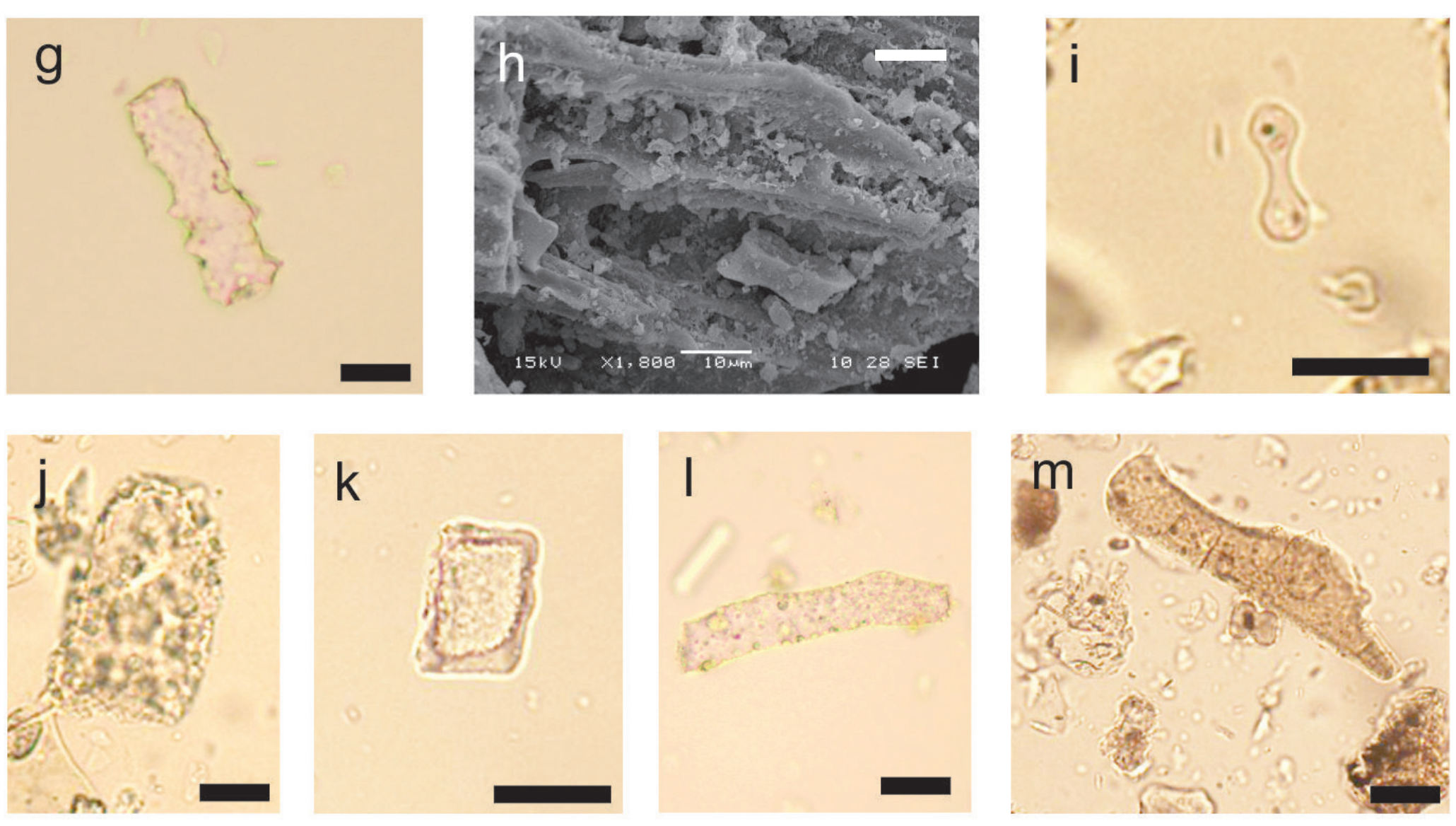

Figure 4 

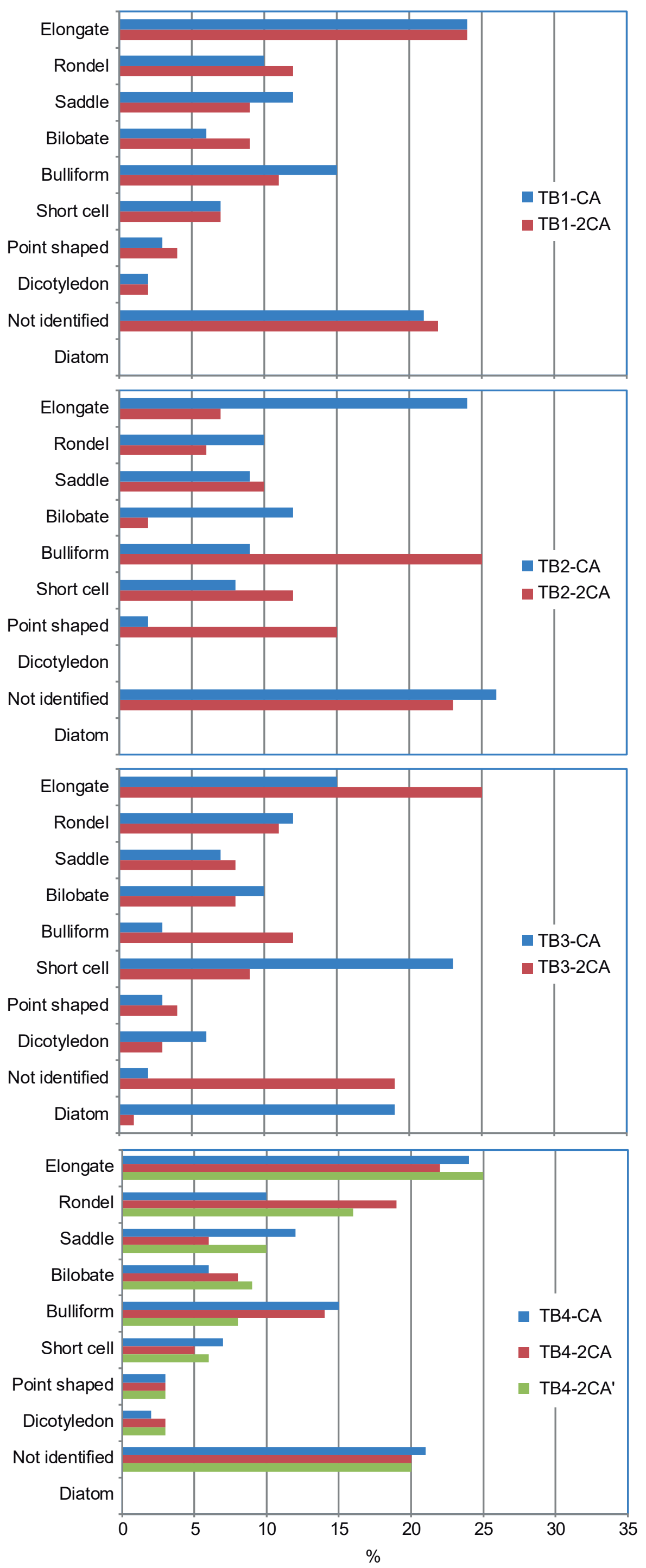

Figure 5 

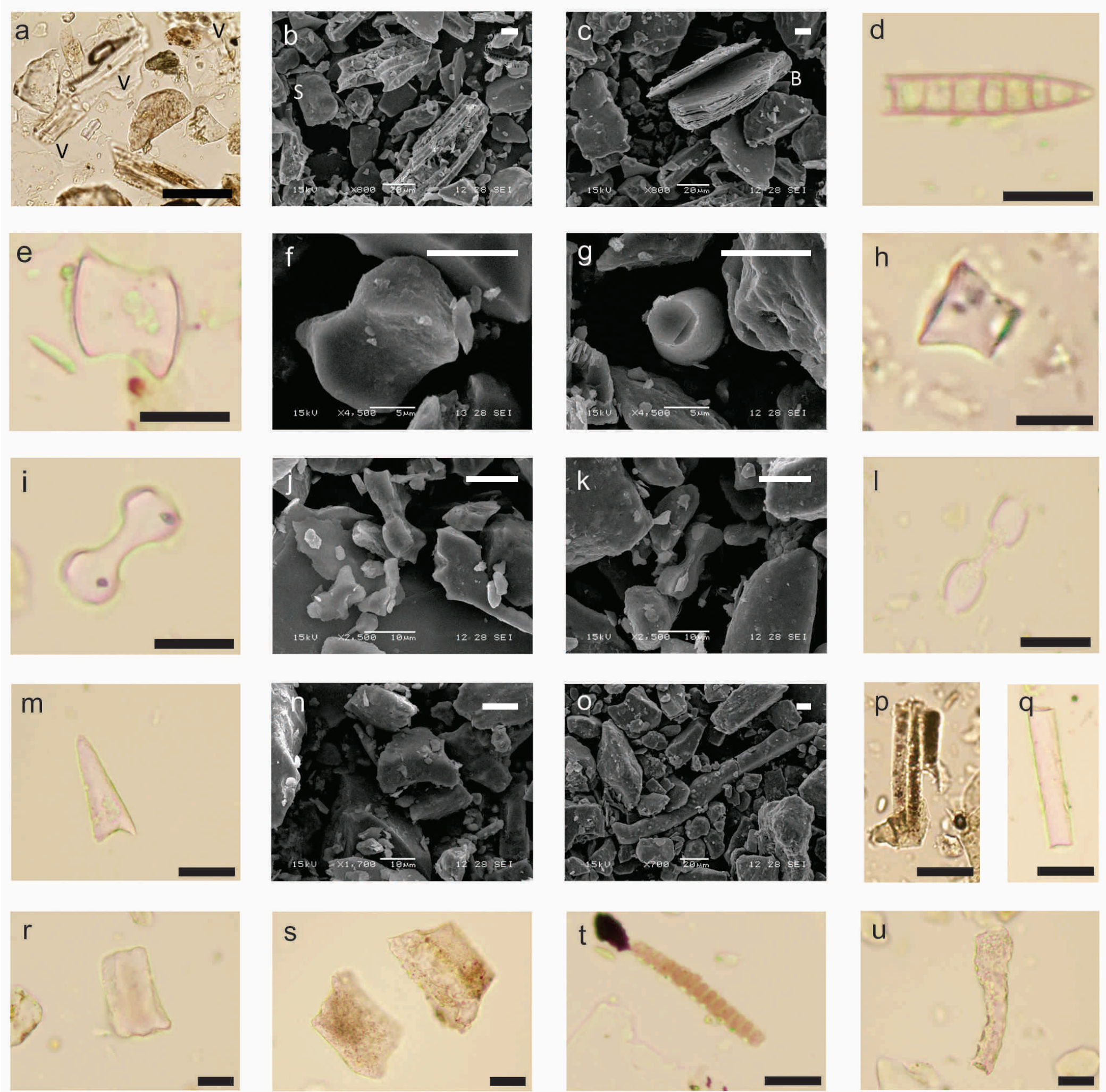

Figure 6 


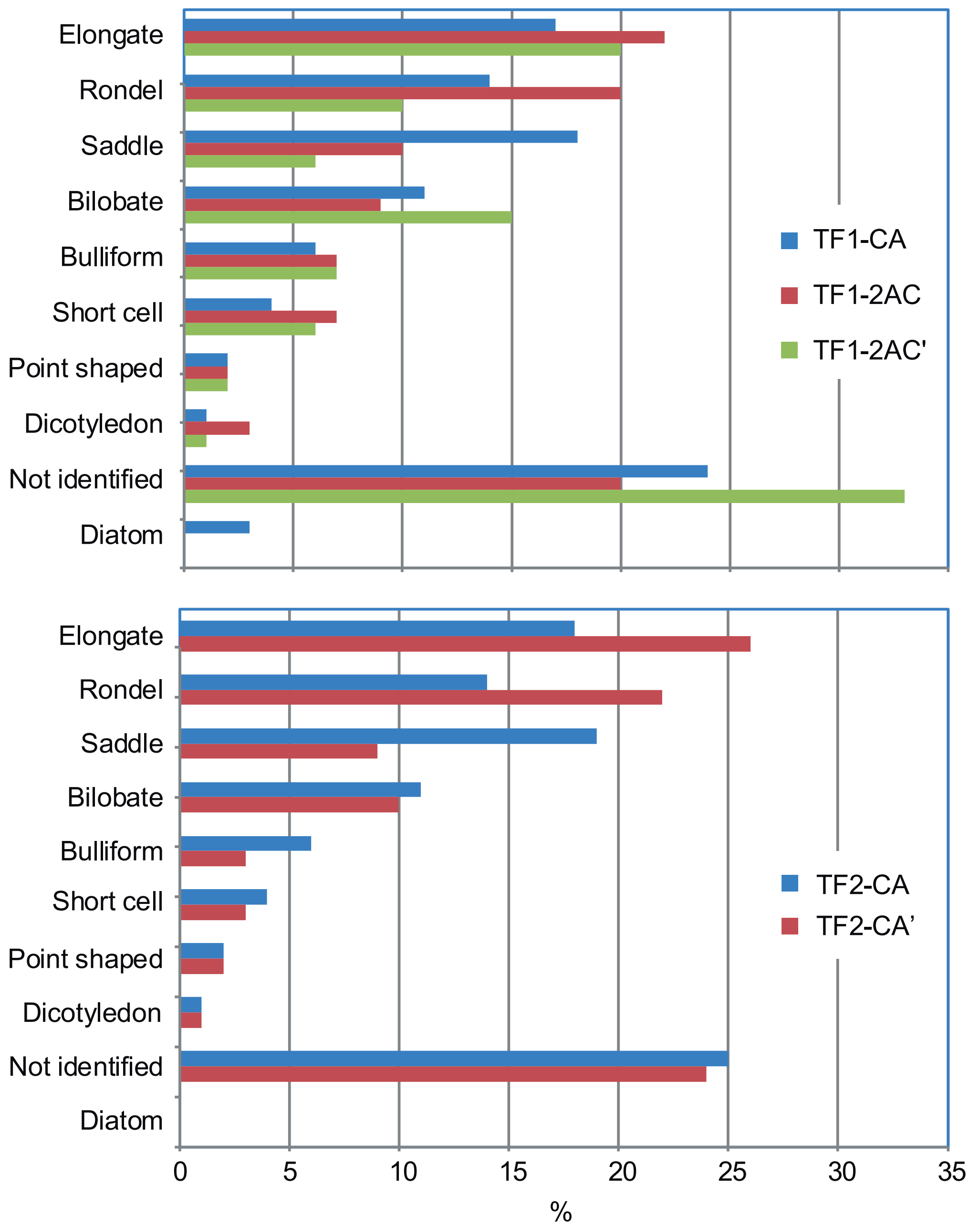

Figure 7 